\title{
EFFECT OF WATER EXTRACT FROM CHAMOMILE ON BLACK BEAN APHID AND COLORADO POTATO BEETLE
}

\author{
Barbara Biniaś', Janina Gospodarek ${ }^{1}$ \\ 1 University of Agriculture in Krakow, Department of Agricultural Environment Protection, Al. Mickiewicza 21, \\ 31-120 Krakow, Poland, e-mail: binias.barbara@gmail.com
}

Received: 2017.02.27

Accepted: 2017.04 .04 Published: 2017.05.02

\begin{abstract}
The aim of the study was to determine the effect of aqueous extracts of dried chamomille (Matricaria chamomilla L.), in concentrations of $2 \%, 5 \%$ and $10 \%$, and fresh parts of this plant, in concentrations of $10 \%, 20 \%$ and $30 \%$ on survival of black bean aphid (Aphis fabae Scop.) on the leaves of broad bean (Vicia faba L.) variety "Bartek" and on feeding of Colorado potato beetle (Leptinotarsa decemlineata Say.) on the leaves of potato (Solanum tuberosum L.) variety "Bellarosa". In these researches on impact of water extracts from chamomille on mortality of wingless females and larvae of black bean aphid, 15 laboratory's observations in the 8-hour intervals was made. In the studies of the effects of aqueous extracts of chamomille on the dynamics of Leptinotarsa decemlineata feeding on the potato leaves, 4 laboratory's observations in 12-hour intervals was made. Observations were carried out in 6 replicates divided into L2 and L4 larvae stages. Aquatic extracts of chamomile limited the survival of black bean aphid larvae and wingless females - the higher the concentration, the stronger the effects of the extract, where young insects were found to be more susceptible. Extracts of the dried plant whose concentration was below 5\% and extracts of the fresh plant whose concentration was below $20 \%$ were found to be ineffective against black bean aphids. In all the analysed concentrations the aquatic extracts of chamomile were found to be ineffective against L2 and L4 larvae of Colorado potato beetle.
\end{abstract}

Keywords: biological control, Matricaria chamomilla L., Aphis fabae Scop., Leptinotarsa decemlineata Say., plant extracts

\section{INTRODUCTION}

The principal problem of contemporary organic farming is the absence of natural plant protection products which could provide an alternative to chemicals. The application of natural plant protection products, e.g. plant extracts based on herbs, is also fully consistent with the recommendations of integrated crop protection. The focus here should be to assess the properties of common plants in order to minimise production costs and reduce their populations in farm fields. Moreover, such products are safe for human health and have zero impact on the natural environment, in particular, they do not lead to accumulation of harmful elements in plants and soil [Bunescu et al. 2003, Szymona 2010].
Chamomile (Matricaria chamomilla L.), formerly known as Chamomilla recutita, is an annual plant of the aster family (Asteraceae). It grows commonly as weed in meadows and farm fields cultivated with cereals, potatoes, beets and near clover and maize [Singh et al. 2011]. Chamomile is commonly used for therapeutic purposes in herbal medicine as it has antibacterial and antiseptic properties [Salamon 1992, Mann and Staba 2002]. It is easy to cultivate and grows best in chalky soils in locations exposed to a lot of sunlight. It blooms from May to early June and can grow up to around $50 \mathrm{~cm}$ [Das et al. 1998]. Chamomile contains an essential oil composed of sesquiterpenes (chamazulene-1,4-dimethyl7-ethylazulene, cadinene, myrcene-7-methyl-3-methylene-1,6-octadiene, spatulenol), 
$\beta$-farnesene, flavonoids (comosin, luteolin-2-(3,4dihydroxyphenyl)-5,7-dihydroxy-4-chromeone, quercetin, patuletin, chrysosplenium), chrysoeriol, hydroxycoumarins (umbelliferone, herniarin7-methoxycoumarin, apigenin), ó-bisabolene (6-methyl-(4-methylcyclohex-3enil)-hepta-2,5dien), choline, bisabolol and sugars, carotenoids, organic acids (salicylic, nicotinic, malic, valeric and tiglic acid), phenolic acids, bitter substances (azulene- isomer naphthalene bicyclo[5,3,0]decapentaene), vitamins and minerals [Reihling et al. 1984]. The main active ingredients include: bisabolol, which has the strongest properties, and chamazulene, $\beta$-farnesene and coumarins [Wyllie et al. 1987].

Black bean aphid (Aphis fabae Scop.) is a major polyphagous pest of agricultural crops. The pest can lead to death of plants and its occurrence always results in reduced yield quantity and quality. Aphids feed on plants by sucking away sap and pose an indirect threat by acting as a vector for viruses [Gospodarek 2012]. A. fabae feed on a number of farm plants, e.g. beetroot, broad bean or other beans, and certain weeds and industrial crops [Gospodarek 2004, Cichocka et al. 2002, Szwejda 2014, Ropek and Kulig 2011, Barczak 1988, Hurej and Van der Werf 1993, Jakubowska and Majchrzak 2013].

Colorado potato beetle (Leptinotarsa decemlineata Say.) (Coleoptera, Chrysomelidae), is a major pest of potato crops in the world [Alyokhin et al. 2008, Maharijaya and Vosman 2015, Olle et al. 2015]. The larvae and adults of $L$. decemlineata feed on the leaves of potato. By eliminating the leaves they weaken the plant and reduce yield [Alyokhin and Atlihan 2005, Kaniuczak and Bereś 2008]. In source literature there is a few publications on the ways to eliminate the insects through the use of non-chemical products based on aquatic plant extracts. However, they concern other plant species and point to a diversity of outcomes relative to the type of applied substance and the stage of development of the insect [Biniaś et al. 2015, Biniaś et al. 2016, Rusin et al. 2015, Rusin et al. 2016]. The research aimed to determine the effects of aquatic extracts of chamomile (Matricaria chamomilla L.) on mortality of black bean aphid (Aphis fabae Scop.) feeding on broad bean (Vicia faba L.) and on feeding of Colorado potato beetle larvae (Leptinotarsa decemlineata Say.) on potato leaves (Solanum tuberosum L.).

\section{MATERIALS AND METHODS}

The laboratory experiment involved fresh, young leaves of broad bean of Bartek cultivar and potato leaves Bellarosa cultivar, collected from the same level below the top of the plant, in order to eliminate an effect of leaf age on the intensity of pest feeding. The collected plant material was treated with aqueous extracts prepared from dry and fresh parts of chamomile (leaves and young shoots). In order to prepare the extracts, $2 \mathrm{~g}, 5$ $\mathrm{g}$ and $10 \mathrm{~g}$ of dry mass of the chamomile were weighed (referred to as the concentration of $2 \%$, $5 \%$ and $10 \%$ ), as well as $10 \mathrm{~g}, 20 \mathrm{~g}$ and $30 \mathrm{~g}$ of fresh mass of the plant (referred to as the concentration of $10 \%, 20 \%$ and $30 \%$ ) [Wawrzyniak and Dębek-Jankowska 2010] and then it was poured with $100 \mathrm{ml}$ of cold double-distilled water. The extracts were allowed to stand for 24 hours in the dark at room temperature. Then, the solutions were filtered through a filter paper, and immediately used for the experiment. The broad bean and potato leaves were immersed for 3 seconds in a suitable extract or double-distilled water (control), then dried at room temperature and placed in Petri dishes lined with moistened filter paper. The chamomile used in the experiment came from own cultivation conducted by Department of Agricultural Environment Protection, using organical methods. Then, 10 individuals of black bean aphids were placed in each dish, the experiment was conducted separately for wingless females and 6-day larvae. In the case of Colorado potato beetle, 2 larvae were placed in each Petri dish. The experiment was conducted separately for L2 and L4 larvae. The mass changes of the food eaten by larvae of $L$. decemlineata was measured 4 times at 12 hour intervals, while 15 observations were performed in the case of black bean aphid, where mortality of the insects was investigated every 8 hours. Both experiments were performed in 6 replicates. The filter paper in Petri dishes was wetted if necessary during the experiments to prevent drying the leaves.

Statistical analysis of the obtained results was conducted using the Statistica 10.0 PL software. The significance of the differences between means was tested via conduct of a single variant variance analysis (the study factor was extract type - prepared from fresh weight or dry weight and at different concentration) and the means were differentiated using the NIR Fisher test at the significance level of $\alpha=0.05$. 


\section{RESULTS AND DISCUSSION}

The aquatic extract of fresh chamomile in $30 \%$ concentration had a significant impact on mortality of black bean aphid larvae feeding on broad bean throughout the entire experiment (Figure 1, Table 1). During most observations the effects of the extract were found to be much stronger also compared to the other analysed extracts. Comparable effects in terms of insecticidal potential were shown by $10 \%$ extract of dried chamomile. First killed aphids were identified after only 8 hours. In general, the higher the concentration of the extract, the greater the mortality of aphids. Throughout most of the experiment the greatest effects were shown by aquatic extracts of fresh chamomile and extract of dried chamomile in the highest concentration (10\%). The $2 \%$ and $5 \%$ extracts of the dried plant did not cause any significant change in mortality of aphid larvae.
The application of aquatic extracts of dried and fresh chamomile led also to increased mortality of wingless black bean aphid females (Figure 2 , Table 2). As in the case of the larvae, the $30 \%$ extract of dried chamomile caused the greatest increase in mortality, followed by the $10 \%$ extract of the dried plant and the $20 \%$ extract of fresh chamomile. $2 \%$ and $5 \%$ extracts of the dried plant and $10 \%$ extract of the fresh plant did not lead to any significant changes in mortality of female A. fabae throughout the observations. In general, the effects of the extracts were less significant in female aphids compared to the larvae.

The analysis of changes in mass of potato leaves consumed by L2 larvae of Colorado potato beetle showed that aquatic extracts of chamomile, irrespective of the type of material used (dried or fresh plant) and the concentration of the extract, did not limit its desire to feed.

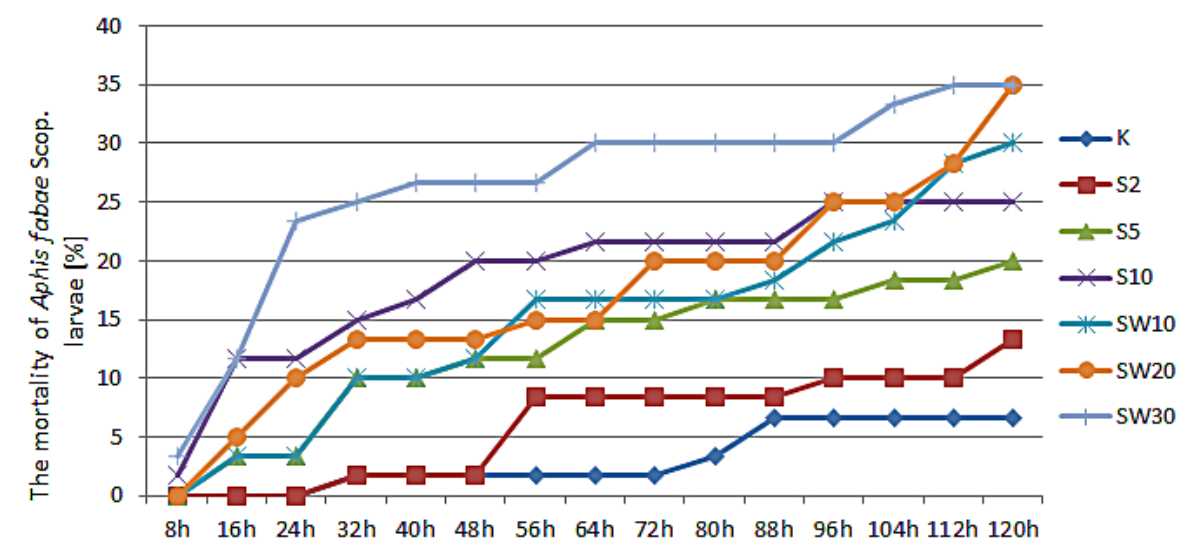

Figure 1. The mortality of black bean aphid larvae (Aphis fabae Scop.) after application of the aqueous extract of dried chamomille in concentrations of $2 \%$ (S2), $5 \%$ (S5) and 10\% (S10), and fresh parts of the plants at concentrations of $10 \%$ (SW10), 20\% (SW20) and 30\% (SW30) compared to the control (K)

Table 1. Results of the statistical analysis of the mortality of the black bean aphid larvae Aphis fabae Scop. feeding on the broad bean leaves, after an application of an aqueous extract of dried and fresh parts of chamomille. See figure 1 for explanations

\begin{tabular}{|c|c|c|c|c|c|c|c|c|c|c|c|c|c|c|c|}
\hline 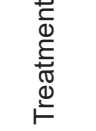 & ळ & $\frac{5}{6}$ & $\underset{\sim}{\stackrel{f}{N}}$ & స్ల & 둥 & 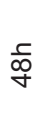 & 离 & 守 & ลิ & 동 & $\begin{array}{l}\text { న్ } \\
\infty\end{array}$ & $\frac{\overline{0}}{\varnothing}$ & $\stackrel{f}{\text { f }}$ & $\underset{⿱}{\stackrel{N}{\leftarrow}}$ & 옳 \\
\hline $\mathrm{K}$ & ${ }^{*} a$ & $a$ & $a$ & $a$ & $a$ & $a$ & $a$ & $a$ & $a$ & $a$ & $a$ & $a$ & $a$ & $a$ & $a$ \\
\hline S2 & $a$ & $a$ & $a$ & $a$ & $a$ & $a$ & $a b$ & $a b$ & $a b$ & $a b$ & $a b$ & $a$ & $a b$ & $a$ & $a b$ \\
\hline S5 & $a$ & a & $a b$ & $a b$ & $a b$ & $b$ & $b c$ & bc & $\mathrm{bc}$ & $b c$ & $b c$ & $a b$ & $b c$ & $a b$ & bc \\
\hline S10 & $a b$ & $b$ & c & $b$ & $b$ & $b c$ & $c d$ & $\mathrm{~cd}$ & $c d$ & $\mathrm{~cd}$ & $c d$ & $b c$ & $\mathrm{~cd}$ & $b c$ & bed \\
\hline SW10 & $a$ & $a$ & $a b$ & $a b$ & $a b$ & $b$ & $b c$ & $b c$ & $b c$ & $b c$ & $\mathrm{c}$ & $b c$ & $\mathrm{~cd}$ & $b c$ & $c d$ \\
\hline SW20 & $a$ & $a$ & $b c$ & $\mathrm{~b}$ & $\mathrm{~b}$ & $\mathrm{~b}$ & $\mathrm{bc}$ & $\mathrm{bc}$ & $\mathrm{c}$ & $\mathrm{C}$ & $\mathrm{C}$ & $\mathrm{bc}$ & $\mathrm{cd}$ & $\mathrm{bc}$ & $\mathrm{d}$ \\
\hline SW30 & $\mathrm{b}$ & b & d & c & c & c & d & d & $\mathrm{d}$ & $\mathrm{d}$ & $\mathrm{d}$ & $c$ & $\mathrm{~d}$ & $c$ & d \\
\hline
\end{tabular}

* Means marked with the same letters in columns do not differ significantly at $\alpha=0.05$. 




Figure 2. The mortality of wingless females of black bean aphid (Aphis fabae Scop.) feeding on the broad bean leaves, after application of the aqueous extract of dried, and fresh parts of chamomille compared to the control (K). See figure 1 for explanations

Table 2. Results of the statistical analysis of the mortality of the wingless females of black bean aphid Aphis fabae Scop. feeding on the broad bean leaves, after an application of an aqueous extract of dried and fresh parts of chamomille. See figure 1 for explanations.

\begin{tabular}{|c|c|c|c|c|c|c|c|c|c|c|c|c|c|c|c|}
\hline 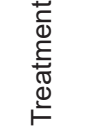 & $\stackrel{ᄃ}{\infty}$ & $\frac{\sigma}{6}$ & $\stackrel{\text { 壬 }}{\sim}$ & స్ల & 하 & $\frac{\text { c }}{\infty}$ & ণ্ & 守 & స̃ & ऽ & $\begin{array}{l}\text { 怘 } \\
\infty\end{array}$ & ㄷㅇㅇ & 守 & $\stackrel{\stackrel{ }{N}}{\rightleftharpoons}$ & ్ㅗㅁ \\
\hline $\mathrm{K}$ & ${ }^{*} a$ & $a$ & $a b$ & $a$ & $a$ & $a$ & $a$ & $a$ & $a$ & $a$ & $a$ & $a$ & $a$ & a & $a$ \\
\hline S2 & $a$ & $a$ & a & $a$ & $a$ & $a b$ & $a b$ & $a b$ & $a b$ & $a b$ & $a b$ & $a$ & $a b$ & $a b$ & $a b$ \\
\hline S5 & $a b$ & $a$ & $a b$ & $a b$ & $a b$ & $a b$ & $a b$ & $a b$ & $a b$ & be & $a b$ & $a b$ & be & $a b c$ & $a b$ \\
\hline $\mathrm{S} 10$ & $a b$ & $b$ & be & $a b$ & $a b$ & be & $b$ & $b$ & be & $\mathrm{c}$ & $b$ & $a b$ & $\mathrm{~cd}$ & bed & be \\
\hline SW10 & $a$ & $a$ & $a b$ & $a b$ & $a b$ & $a b c$ & $a b$ & $a b$ & $a b$ & $a b c$ & $a b$ & $a b$ & be & $\mathrm{cd}$ & $\mathrm{cd}$ \\
\hline SW20 & $a$ & $a$ & $a b c$ & $a b$ & $a b$ & $a b$ & $a b$ & $a b$ & be & $\mathrm{c}$ & $\mathrm{b}$ & be & $\mathrm{cd}$ & $\mathrm{cd}$ & $d$ \\
\hline SW30 & $\mathrm{b}$ & $b$ & c & $\mathrm{b}$ & b & C & $\mathrm{C}$ & c & 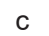 & $d$ & $\mathrm{C}$ & $\mathrm{c}$ & $d$ & $d$ & d \\
\hline
\end{tabular}

* Means marked with the same letters in columns do not differ significantly at $\alpha=0.05$

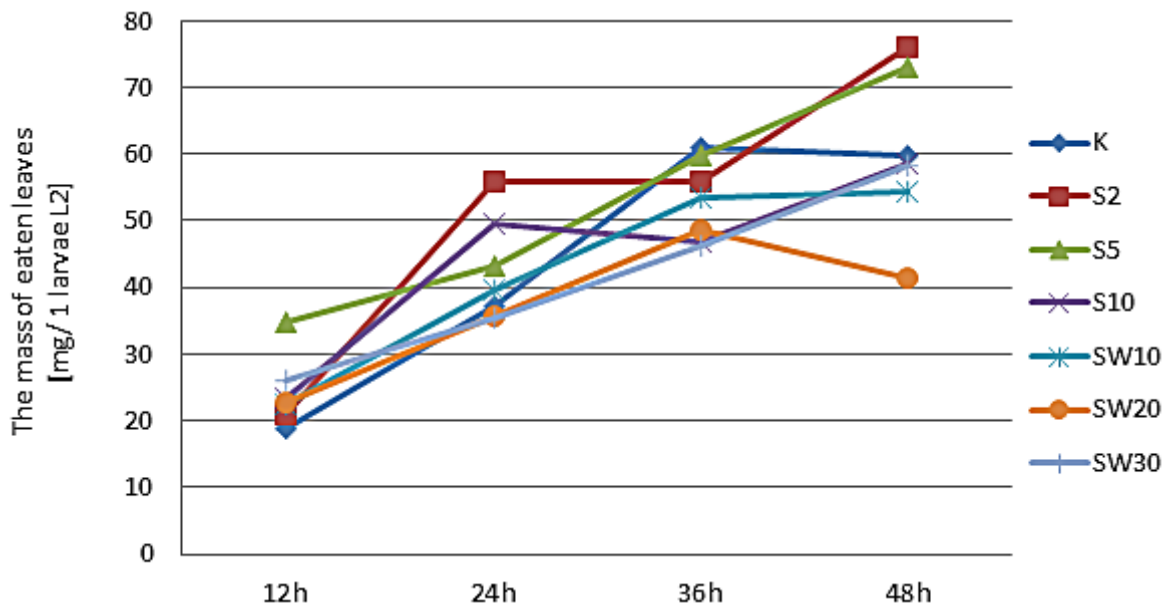

Figure 3. The mass changes of the food (potato leaves) eaten by larvae of Leptinotarsa decemlineata Say. (L2 stage), after application of the aqueous extract of chamomille. See figure 1 for explanations 
Table 3. Results of the statistical analysis of the mass changes of the food (potato leaves) eaten by larvae of Leptinotarsa decemlineata Say. (L2 stage) after application of the aqueous extract of dried and fresh parts of chamomille. See figure 1 for explanations

\begin{tabular}{|c|c|c|c|c|}
\hline Treatment & after $12 \mathrm{~h}$ & after $24 \mathrm{~h}$ & after $36 \mathrm{~h}$ & after $48 \mathrm{~h}$ \\
\hline $\mathrm{K}$ & *a & $a b$ & $a$ & $a b$ \\
\hline S2 & $a$ & $b$ & $a$ & $b$ \\
\hline S5 & b & $a b$ & a & $\mathrm{b}$ \\
\hline $\mathrm{S} 10$ & $a b$ & $a b$ & a & $a b$ \\
\hline SW10 & a & $a b$ & a & $a b$ \\
\hline SW20 & $a b$ & $a$ & $a$ & $\mathrm{a}$ \\
\hline SW30 & $a b$ & a & a & $a b$ \\
\hline
\end{tabular}

* Means marked with the same letters in columns do not differ significantly at $\alpha=0.05$.

The analysis of changes in mass of potato leaves consumed by L4 larvae of Colorado potato beetle showed that none of the analysed extracts had a significant effect (Figure 4, Table 4). Only 48 hours after the start of the experiment the mass consumed by the larvae feeding on leaves treated with the extract of fresh chamomile in the highest concentration (30\%) were found to be signifi- cantly lower compared to those treated with the $5 \%$ and $10 \%$ extract of the dried plant and $20 \%$ extract of the fresh plant.

To sum up the experiment, it was found that the effects of aquatic extracts of chamomile on the larvae and wingless black bean aphid females were limited and the extracts had no effect on the larvae of Colorado potato beetle.

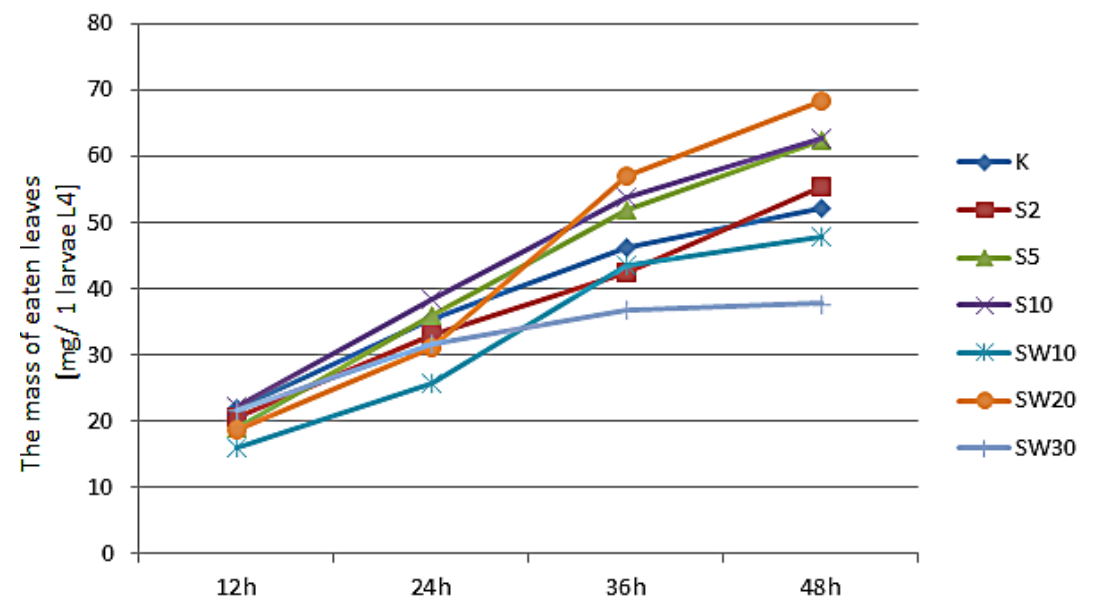

Figure 4. The mass changes of the food (potato leaves) eaten by larvae of Leptinotarsa decemlineata Say. (L4 stage), after application of the aqueous extract of chamomille.

See figure 1 for explanations

Table 4. Results of the statistical analysis of the mass changes of the food (potato leaves) eaten by larvae of Leptinotarsa decemlineata Say. (L4 stage) after application of the aqueous extract of dried and fresh parts of chamomille. See figure 1 for explanations

\begin{tabular}{|c|c|c|c|c|}
\hline Treatment & after $12 \mathrm{~h}$ & after $24 \mathrm{~h}$ & after $36 \mathrm{~h}$ & after $48 \mathrm{~h}$ \\
\hline K & ${ }^{*} \mathrm{a}$ & $\mathrm{a}$ & $\mathrm{a}$ & $\mathrm{ab}$ \\
\hline S2 & $\mathrm{a}$ & $\mathrm{a}$ & $\mathrm{a}$ & $\mathrm{ab}$ \\
\hline S5 & $\mathrm{a}$ & $\mathrm{a}$ & $\mathrm{a}$ & $\mathrm{a}$ \\
\hline S10 & $\mathrm{a}$ & $\mathrm{a}$ & $\mathrm{a}$ & $\mathrm{b}$ \\
\hline SW10 & $\mathrm{a}$ & $\mathrm{a}$ & $\mathrm{a}$ & $\mathrm{ab}$ \\
\hline SW30 & $\mathrm{a}$ & $\mathrm{a}$ & $\mathrm{a}$ & $\mathrm{b}$ \\
\hline
\end{tabular}

*Means marked with the same letters in columns do not differ significantly at $\alpha=0.05$. 
The available source literature lacks any references to the use of aquatic extracts of chamomile in eliminating Colorado potato beetle and black bean aphid. The focus of experiments that involved the plant were alcoholic extracts or essential oils. When it comes to methanolic extracts of chamomile in $0.5 \%$ and $5 \%$ concentration, only the $5 \%$ extract effectively prevented the larvae of Colorado potato beetle from feeding $[\mathrm{Ku}-$ tas and Nadosy 2006]. Extracts based on hexane, ethanol and methanol, made by mixing $1000 \mathrm{ml}$ of solvent with $100 \mathrm{~g}$ of dried M. chamomilla, effectively eliminated the larvae of Colorado potato beetle. The mortality of L3 larvae subject to extracts based on hexane was $32.18 \%$, extracts based on ethanol $-42.87 \%$ and extracts based on methanol $-45.71 \%$. The response of L4 larvae to extracts based on hexane was $24.10 \%$ mortality, with $37.92 \%$ mortality in response to extracts based on ethanol and $44.83 \%$ mortality in response to extracts based on methanol. The above results indicate that the effects of use of the extracts are contingent primarily on the type of used solvent as well as the developmental stage of the insect [Yorulmaz Salman et al. 2015].

The experiments we have conducted so far based on aquatic extracts of absinthe (Artemisia absinthium L.) [Rusin et al. 2015], common nettle (Urtica dioica L.) [Biniaś et al. 2015], common Saint John's wort (Hypericum perforatum L.) [Biniaś et al. 2016] and absinthe (Artemisia absinthium L.) [Rusin et al. 2016] showed that the extracts can prevent Colorado potato beetle larvae and adults from feeding and inhibit their growth. The effects were contingent on the used plant species, concentration of the extract and the development stage of $L$. decemlineata .

The experiments demonstrated that aquatic extracts of fresh chamomile in the highest concentration, i.e. $30 \%$, caused death of around $35 \%$ of black bean aphids - both wingless aphid females and larvae - after 120 hours. In comparison, the aquatic extract of common nettle in the same concentration and after identical time resulted in 64\% mortality of $A$. fabae larvae, and $55 \%$ mortality of wingless females [Biniaś et al. 2015a]. Aquatic extracts of winter savory (Satureja montana L.) made of the dried plant in $10 \%$ concentration and fresh plant in concentration of $20 \%$ and $30 \%$ caused $100 \%$ mortality of wingless black bean aphid females and larvae after 120 hours. The efficiency of extracts grew as the concentration increased [Rusin et al. 2016a]. The aquatic extracts of dried and fresh common sage (Salvia officinalis L.) caused death of around 55\% of wingless females and 49\% larvae [Biniaś et al. 2015b]. The experiment in question, too, indicated that the efficiency of extracts grew as the concentration increased, however, compared to the above values, the efficiency of aquatic extracts of chamomile is very low.

\section{CONCLUSIONS}

1. Aquatic extracts of chamomile limited the survival of black bean aphid larvae and wingless females - the higher the concentration, the stronger the effects of the extract, where young insects were found to be more susceptible.

2. Extracts of the dried plant whose concentration was below 5\% and extracts of the fresh plant whose concentration was below $20 \%$ were found to be ineffective against black bean aphids.

3. In all the analysed concentrations the aquatic extracts of chamomile were found to be ineffective against L2 and L4 larvae of Colorado potato beetle.

\section{Acknowledgments}

This research was financed by the Ministry of Science and Higher Education of the Republic of Poland.

\section{REFERENCES}

1. Alyokhin A., Atlihan R., 2005. Reduced Fitness of the Colorado Potato Beetle (Coleoptera: Chrysomelidae) on Potato Plants Grown in Manureamended Soil. Environ. Entomol. 34(4), 963-968.

2. Alyokhin A., Baker M., Mota-Sanchez D., Dively G.,Grafius E., 2008. Colorado Potato Beetle Resistance to Insecticides. AM J POTATO RES. 85(6), 395-413.

3. Barczak T., 1988. Owady - naturalni wrogowie mszycy trzmielinowo-burakowej (Aphis fabae Scop.) (Homoptera, Aphididae). Wiadomości Entomologiczne. 8(1-2), 13-26.

4. Biniaś B., Gospodarek J., Rusin M., 2015. Wpływ wodnego wyciągu z pokrzywy zwyczajnej (Urtica dioica L.) na żerowanie chrząszczy stonki ziemniaczanej (Leptinotarsa decemlineata Say.). Episteme: Czasopismo Naukowo-Kulturalne, ISSN 1895-4421. 3(26), 149-156. 
5. Biniaś B., Gospodarek J., Rusin M., 2015a. Wpływ wodnego wyciągu z pokrzywy zwyczajnej (Urtica dioica L.) na żywotność mszycy burakowej (Aphis fabae Scop.) na bobie. Episteme: Czasopismo Naukowo-Kulturalne, 3(26), 139-147.

6. Biniaś B., Gospodarek J., Rusin M., 2015b. Wpływ wodnego wyciągu z szałwii lekarskiej (Salvia officinalis L.) na żywotność mszycy burakowej (Aphis fabae Scop.) na bobie. Episteme 27 (1), 61-70.

7. Biniaś B., Gospodarek J., Rusin M., 2016. Effect of aqueous extract of St. John's wort (Hypericum perforatum L.) on the Colorado potato beetle (Leptinotarsa decemlineata Say.) behaviour. Journal of Research and Applications in Agricultural Engineering. 61(3), 25-29.

8. Bunescu H., Ghizdavu I., Mihai G., Oltean I., Porca M., Bodiş I., 2003. The control of pests in ecosystems by unchemical methods. Journal od Central European Agriculture. 4(1), 7-12.

9. Cichocka E., Leszczyński B., Ciepiela A. P., Goszczyński W. 2002. Response of Aphis fabae Scop. to different broad bean cultivars. EJPAU, Horticulture, 5(2). Available Online http://www. ejpau.media.pl.

10. Das M., Mallavarapu G.R., Kumar S., 1998. Chamomile (Chamomilla recutita): Economic botany, biology, chemistry, domestication and cultivation. J Med Aromat Plant Sci. 20, 1074-1109.

11. Gospodarek J. 2004. Wrogowie naturalni Aphis fabae Scop. W środowisku miejskim o różnym stopniu zanieczyszczenia. Post. Ochr. Roślin/ Progr. Plant Protect., 44/2, 699-701.

12. Gospodarek J. 2012. Występowanie mszycy burakowej Aphis fabae Scop. oraz jej drapieżców na bobie w warunkach zanieczyszczenia gleby metalami ciężkimi. Zesz. Nauk. UR w Krakowie nr 480, 202 p.

13. Hurej M., Van der Werf W. 1993. The influence of black bean aphid, Aphis fabae Scop., and its honeydew on leaf growth and dry matter production of sugar beet. Ann. Appl. Biol. 122: 201-214.

14. Jakubowska M., Majchrzak L., 2013. Wpływ tradycyjnej i bezorkowej uprawy roli na zdrowotność i plonowanie buraków pastewnych. Fragmenta Agronomica, 30(1), 45-53.

15. Kaniuczak Z., Bereś P., 2008. The most harmful cereals pests in ecological farms of south-east Poland. J. Res. App. Agric. Engng. 53(3), 28-132.

16. Kutas J., Nadasy M., 2006. Antifeedant effects of several plant extracts on Colorado potato beetle larvae. Acta Phytopathologica et Entomologica Hungarica. 40(3-4), 355-365.

17. Maharijaya A., Vosman B., 2015. Managing the Colorado potato beetle; the need for resistance breeding. Euphytica. 204(3), 487-501.
18. Mann C., Staba E.J., 2002. The chemistry, pharmacology and commercial formulations of chamomile. In: Craker LE, Simon JE, editors. Herbs, spices and medicinal plants- recent advances in botany, Horticulture and Pharmacology. USA: Haworth Press Inc. 235-280.

19. Olle M., Tsahkna A., Tähtjärv T., Williams I., 2015. Plant protection for organically grown potatoes - a review. BIOL AGRIC HORTIC. 31(3), 147-157.

20. Ropek D., Kulig B., 2011. Wpływ uprawy mieszanki bobiku $\mathrm{z}$ owsem nagoziarnistym w systemie ekologicznym na występowanie szkodników. Progr. Plant Prot. 51(3), 1291-1295.

21. Rusin M., Gospodarek J., Biniaś B., 2015. The effect of water extracts from Artemisia absinthium L. on feeding of Leptinotarsa decemlineata Say. larvae. Journal of Research and Applications in Agricultural Engineering. 60(4), 80-83.

22. Rusin M., Gospodarek J., Biniaś B., 2016. Wpływ wodnych wyciągów z bylicy piołunu (Artemisia absinthium L.) na żerowanie wybranych szkodników roślin uprawnych i ich reakcje na zapach tej rośliny. Journal of Central European Agriculture. 17(1), 188-206.

23. Rusin M., Gospodarek J., Biniaś B., 2016a. The effect of water extracts from winter savory on black bean aphid mortality. Journal of Ecological Engineering. 17(1), 101-105.

24. Salamon I., 1992. Chamomile a medicinal plant. J Herbs Spices Med Plants. 10, 1-4.

25. Singh O., Khanam Z., Misra N., Srivastava M. K., 2011. Chamomile (Matricaria chamomilla L.): An overview. Pharmacognosy Review. 5(9), 82-95.

26. Szwejda J., 2014. Szkodliwa entomofauna występująca na uprawach roślin warzywnych w Polsce w latach 1861-2008. Progress In Plant Protection. 54(1), 61-65.

27. Szymona J., 2010. Problem Of Chemical Plant Protection Products' Residues In Organic Raw Material. Journal of Research and Applications in Agricultural Engineering. 55(4), 146-149.

28. Wawrzyniak M., Dębek - Jankowska A., 2010. Oddziaływanie wybranych wodnych wyciągów roślinnych na wołka zbożowego. Progress in Plant Protection. 50(1), 398-401.

29. Wyllie S. G., Cook D., Brophy J. J., Richter Karen M., 1987. Volative falvour components of Annona atemoya. J. Agric Food Chem. 35, 768-770.

30. Yorulmaz Salman S., Kara N., Öz O., 2015. Bazı Bitkilerin Hekzan, Ethanol ve Methanollü Ekstraktlarının Leptinotarsa decemlineata Say. (Coleoptera:Chrysomelidae) ,nın Farklı Dönemleri Üzerine Kontakt Toksisiteleri. Ana Sayfa. 19(1), 124-130. 